\title{
Pengaruh Nilai Tukar, Suku Bunga SBI dan Inflasi Terhadap Indeks Harga Saham Gabungan Di Bursa Efek Indonesia
}

Macroeconomic factors in

Composite Stock Proce Index

\author{
Paryudi, Dr. Gendro Wiyono, M.M , Risal Rinofah, SE., M.Sc \\ Fakultas Ekonomi Universitas Sarjanawiyata Tamansiswa, Yogyakarta, Indonesia \\ Email : paryudi206@gmail.com
}

\section{ABSTRACT}

This study aims to determine the effect of exchange rates, Interest Rates Sertificates of Bank Indonesia and inflation on the Composite Stock Price Index in the Indonesian stock exchange. The sampling technique was purposive sampling. The samples obtained were 60 samples. Based on the results of data analysis, it shows that the exchange rate has a negative and significant effect on the Composite Stock Price Index. Interest Rates Certificates of Bank Indonesia and Inflation has a negative and unsignificant effect on the Composite Stock Price Index. Collectively exchange rate, Interest Rates, Certificate of Bank Indonesia and inflation have a positive and significant effect on the Composite Stock Price Index.

Keywords: exchange rates, Interest Rates Certificates of Bank Indonesia, inflation and Composite Stock Price Index.

Keywords: Exchange rates, Interest Rates Certificates of Bank Indonesia, inflation and Composite Stock Price Index.

\section{PENDAHULUAN}

Pasar modal menjadi indikator utama bagi perekonomian suatu negara, hal ini karena pasar modal memiliki peranan penting bagi kemajuan perekonomian khususnya di negara yang menganut sistem ekonomi pasar. Pasar modal dapat menjadi sumber dana alternatif bagi suatu perusahaan, salah satu sumber dana dari perusahaan yang berasal dari modal saham yang ditanamkan oleh para investor.

Analisis faktor ekonomi adalah salah satu faktor yang tidak dapat dipisahkan dan merupakan bagian penting dari keseluruhan faktor fundamental itu sendiri. Analisis ekonomi memiliki integrasi yang sangat kuat terhadap keadaan pasar modal (Sudarsana \& Candraningrat, 2014). Berdasarkan analisis ekonomi dikatakan adanya kecenderungan hubungan yang kuat antara lingkungan ekonomi makro dengan kinerja suatu pasar modal. Beberapa variabel ekonomi nasional yang biasanya digunakan adalah tingkat pertumbuhan ekonomi yang biasanya dilihat dari tingkat inflasi, tingkat suku bunga dan nilai tukar rupiah. Tandelilin (2010) menyatakan bahwa faktor-faktor makroekonomi secara empiris telah terbukti mempunyai pengaruh terhadap kondisi pasar modal di beberapa negara.

Nilai tukar rupiah merupakan perbandingan nilai atas harga rupiah dengan harga mata uang asing, masing- masing negara memiliki nilai tukarnya sendiri yang mana nilai tersebut merupakan perbandingan nilai suatu mata uang dengan mata uang lainnya yang disebut dengan kurs valuta asing (Sudarsana \& Candraningrat, 2014). Informasi nilai tukar rupiah terhadap US dollar umumnya sangat diperhatikan oleh perusahaan-perusahaan di Indonesia, karena selain US dollar digunakan oleh perusahaan secara umum untuk melakukan pembayaran bahan produksi dan transaksi bisnis-bisnis lainnya.
Submitted: MARET 2021

Accepted: JUNI 2021

\section{JIMKES}

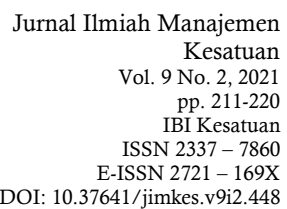


Macroeconomic

factors in

Composite Stock

Proce Index

212

Tingkat suku bunga menyatakan tingkat pembayaran atas pinjaman atau investasi lain, di atas perjanjian pembayaran kembali, yang dinyatakan dalam persentase tahunan (Kewal, 2012). Suku bunga BI merupakan tingkat suku bunga yang ditetapkan oleh BI sebagai patokan bagi suku bunga pinjaman maupun simpanan bagi bank dan atau lembagalembaga keuangan di seluruh Indonesia. Suku bunga merupakan salah satu variabel yang dapat mempengaruhi harga saham. Perubahan tingkat suku bunga selanjutnya akan mempengaruhi keinginan seseorang untuk melakukan suatu investasi, karena secara umum perubahan suku bunga SBI dapat mempengaruhi suku bunga deposito dan suku bunga kredit di masyarakat (Amin, 2012). Jika suku bunga deposito meningkat maka investor cenderung menanamkan modalnya dalam bentuk deposito karena dapat menghasilkan return yang besar dengan resiko yang lebih kecil dan sebaliknya. Dalam penelitian ini suku bunga SBI menggunakan data suku bunga SBI bulanan yang dipublikasikan oleh Bank Indonesia.

Menurut Putong (2013) inflasi didefinisikan sebagai naiknya harga komoditi yang disebabkan oleh tidak sinkronnya antara program sistem pengadaan komoditi dengan tingkat pendapatan yang dimiliki oleh masyarakat di suatu negara tertentu. Inflasi tidak akan menjadi permasalahan ekonomi apabila diiringi oleh tersedianya komoditi yang diperlukan secara cukup dan diikuti dengan naiknya tingkat pendapatan yang lebih besar dari tingkat inflasi tersebut. Apabila biaya produksi untuk menghasilkan komoditi semakin tinggi, maka menyebabkan harga jual relatif tinggi. Sementara disisi lain tingkat pendapatan masyarakat relatif tetap tidak ada perubahan, maka inflasi akan menjadi masalah ekonomi bila berlangsung dalam waktu yang relatif lama dengan porsi berbanding terbalik antara tingkat inflasi terhadap tingkat pendapatan. Nugroho (2012) mendefinisikan inflasi secara singkat yaitu kecenderungan harga naik secara umum dan terus menerus, atau dapat diartikan sebagai penurunan nilai uang secara menyeluruh, makin tinggi kenaikan harga maka makin turun nilai uang.

Pasar modal juga merupakan representasi untuk menilai kondisi perusahaan di suatu negara, karena hampir semua industri di suatu Negara terwakili oleh pasar modal. Pasar modal yang mengalami peningkatan (bullish) atau mengalami penurunan (bearish) terlihat dari naik turunnya harga harga saham yang tercatat yang tercermin melalui suatu pergerakan indeks atau lebih dikenal dengan Indeks Harga Saham Gabungan (IHSG). IHSG merupakan nilai yang digunakan untuk mengukur kinerja gabungan seluruh saham (perusahaan/emiten) yang tercatat di Bursa Efek Indonesia (BEI). Banyak teori dan penelitian terdahulu yang mengungkapkan bahwa pergerakan Indeks Harga Saham Gabungan (IHSG) dipengaruhi oleh beberapa faktor. Seperti faktor yang berasal dari luar negeri (eksternal) dan faktor yang berasal dari dalam negeri (internal). Faktor yang berasal dari luar negeri tersebut bisa datang dari indeks bursa asing negara lain (Dow Jones, Hang Seng, Nikkei, dll), tren perubahan harga minyak dunia, tren harga emas dunia, sentimen pasar luar negeri, dan lain sebagainya. Sedangkan faktor yang berasal dari dalam negeri bisa datang dari nilai tukar atau kurs di suatu negara terhadap negara lain, tingkat suku bunga dan inflasi yang terjadi di negara tersebut, kondisi sosial dan politik suatu negara, jumlah uang beredar dan lain sebagainya.

Penelitian ini memiliki rumusan masalah sebagai berikut :

a. Apakah nilai tukar berpengaruh terhadap indeks harga saham gabungan?

b. Apakah suku bunga berpengaruh terhadap indeks harga saham gabungan?

c. Apakah inflasi berpengaruh terhadap indeks harga saham gabungan?

d. Apakah nilai tukar, suku bunga dan inflasi berpengaruh terhadap indeks harga saham gabungan? 


\section{Kerangka Pemikirian}

Kerangka pemikiran dalam penelitian ini adalah sebagai berikut :

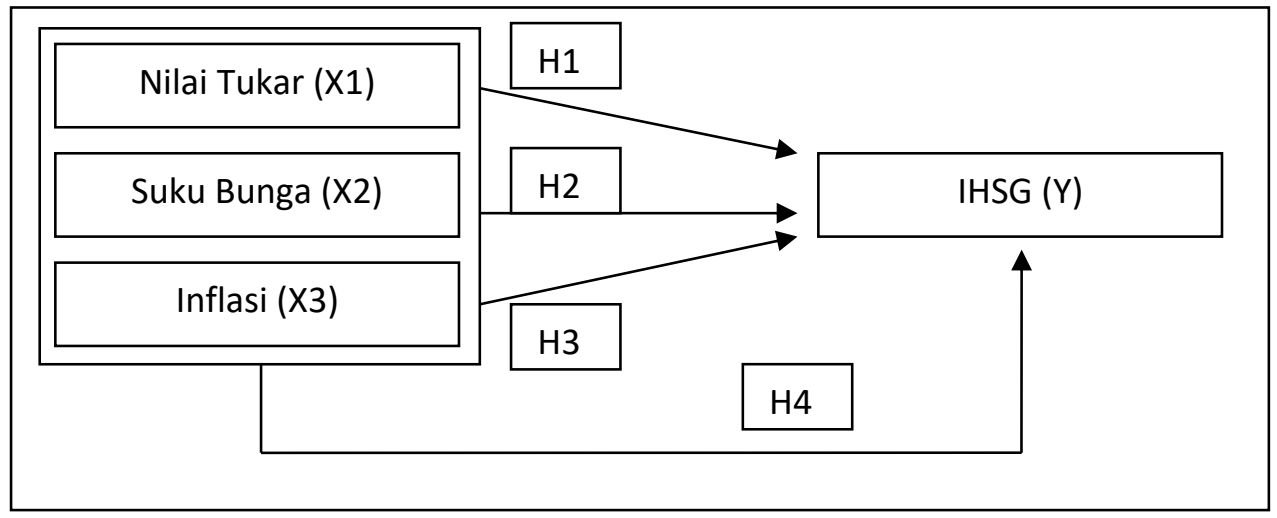

Macroeconomic factors in Composite Stock Proce Index

\section{Hipotesis Penelitian}

Gambar 1. Kerangka Pemikiran

Berdasarkan tujuan penelitian, perumusan masalah dan kerangka pemikiran di atas, peneliti memberikan hipotesis adalah sebagai berikut, yaitu :

H1 : Pengaruh Nilai Tukar terhadap Indeks Harga Saham Gabungan

H2 : Pengaruh Suku Bunga terhadap Indeks Harga Saham Gabungan

H3 : Pengaruh Inflasi terhadap Indeks Harga Saham Gabungan

H4 : Pengaruh Nilai Tukar, Suku Bunga dan Inflasi terhadap Indeks Harga Saham

Gabungan

\section{METODOLOGI PENELITIAN}

\section{Metode dan Sifat Penelitian}

Penelitian ini bersifat korelasional, karena di dalam penelitian ini bertujuan untuk menemukan ada tidaknya hubungan antara 2 variabel atau lebih. Penelitian ini juga dilakukan untuk mengetahui ada tidaknya dan kuat lemahnya hubungan variabel yang berkaitan dalam suatu objek atau subjek yang diteliti. Penelitian ini dimaksudkan untuk mengetahui pengaruh nilai tukar rupiah, suku bunga, dan inflasi terhadap indeks harga saham gabungan di Bursa Efek Indonesia Periode 2015-2019.

\section{Populasi}

Populasi yang digunakan dalam penelitian ini adalah seluruh data time series bulanan meliputi nilai tukar, tingkat suku bunga SBI, inflasi dan Indeks Harga Saham Gabungan periode Januari 2016 - Desember 2020 sebanyak 60.

\section{Sampel}

Teknik pengambilan sampel dalam penelitian ini menggunakan metode purposive sampling, pengambilan sampel dengan menetapkan kriteria tertentu. Berdasarkan keterangan tersebut, diperoleh jumlah sampel (n) dari data time series bulanan yaitu sebanyak 60 sampel (12 bulan x 5 tahun).

\section{Jenis dan Sumber Data}

Dalam penelitian ini penulis menggunakan sumber data sekunder dalam bentuk time series bulanan selama 5 tahun. Sumber data berasal dari laporan publikasi yang diterbitkan oleh Bursa Efek Indonesia tahun 2015-2019.

\section{Identifikasi Variabel}

1. Variabel independent (bebas) : Nilai Tukar (X1), Suku Bunga (X2), dan Inflasi (X3).

2. Variabel dependent (terikat) yaitu : Indeks Harga Saham Gabungan (Y1) 
Macroeconomic

factors in

Composite Stock

Proce Index

214
HASIL DAN PEMBAHASAN

Analisis Deskriptif

Statistik deskriptif digunakan untuk mengetahui deskripsi pada suatu data yang dilihat dari nilai maksimum, nilai minimum, nilai rata-rata (mean), dan nilai standar deviasi. Tabel 1 Hasil Statistik Deskriptif

\section{Descriptive Statistics}

\begin{tabular}{|c|c|c|c|c|c|}
\hline & $\mathrm{N}$ & Minimum & Maximum & Mean & Std. Deviation \\
\hline IHSG & 60 & 4538.93 & 6605.63 & 5692.2270 & 581.36605 \\
\hline NILAI TUKAR & 60 & 12998.00 & 16367.00 & 13950.2333 & 646.66661 \\
\hline SBI & 60 & 3.75 & 7.25 & 5.1083 & .88701 \\
\hline INFLASI & 60 & 1.32 & 4.45 & 3.1205 & .74047 \\
\hline Valid N (listwise) & 60 & & & & \\
\hline
\end{tabular}

Sumber: Data diolah 2021

Berdasarkan Tabel 1 tersebut, dapat dilihat bahwa rata-rata IHSG sebesar 5692,2270, nilai minimum sebesar 4538,93, dan nilai maksimum sebesar 6605,63. Rata-rata nilai tukar sebesar 13950,2333, nilai terendah sebesar 12998,00; dan nilai tertinggi sebesar 16367,00. Suku Bunga SBI memiliki nilai rata-rata sebesar 5,1083, nilai minimum sebesar 3,75; dan nilai maksimum sebesar 7,25. Inflasi memiliki nilai rata-rata sebesar 3,1205, nilai terendah sebesar 1,32 dan nilai tertinggi sebesar 4,45.

Tabel 2 Uji Normalitas

Hasil Uji Normalitas

Unstandardized

Residual

Asymp. Sig. (2-tailed)

0,818

Sumber: Data diolah 2021

Berdasarkan tabel 4.2 tersebut terlihat bahwa nilai Sig. (2-tailed) sebesar 0,818 $>0,05$ maka dapat disimpulkan bahwa nilai residual berdistribusi normal karena lebih besar dari 0,05 .

Tabel 3 Uji Multikolinearitas

\begin{tabular}{llll} 
& \multicolumn{3}{c}{ Hasil Uji Multikolinearitas } \\
Model & Tolerance & FIV & Keterangan \\
\hline 1 (Constant) & & & \\
Lag_NilaiTukar & 0,992 & 1,008 & Tidak Terjadi Multikolinearitas \\
Lag_SBI & 0,993 & 1,007 & Tidak Terjadi Multikolinearitas \\
Lag_Inflasi & 0,993 & 1,008 & Tidak Terjadi Multikolinearitas
\end{tabular}

a. Dependent Variable: Lag_IHSG

Berdasarkan Tabel 3 di atas, nilai Tolerance variabel bebas Nilai Tukar $=0,992$, Suku Bunga $\mathrm{SBI}=0,993$, Inflasi $=0,993$. Sedangkan nilai VIF variabel bebas Nilai Tukar $=1,008$, Suku Bunga SBI $=1,007$, Inflasi $=1,008$. Dapat disimpulkan bahwa model regresi dinyatakan bebas dari multikolinearitas.

Tabel 4 Uji Autokorelasi

\begin{tabular}{lll}
\hline & \multicolumn{2}{c}{ Hasil Uji Autokolerasi } \\
& $\begin{array}{l}\text { Unstandarized } \\
\text { Residual }\end{array}$ & Keterangan \\
\hline Asymp. Sig. (2-tailed) & 0,238 & Tidak Terjadi Autokorelasi \\
\hline Sumber: Data diolah 2021 &
\end{tabular}


Berdasarkan tabel 4 di atas nilai Asymp. Sig. (2-tailed) sebesar 0,238 yang artinya nilai signifikansinya dari Standarized Residual > dari 0,05 $(0,238>0,05)$. Hasil ini menunjukan bahwa variabel data tersebut bersifat tidak terjadi autokorelasi.

Tabel 5 Uji Heterokedastisitas

Hasil Uji Heterokedastisitas

Variabel Sig Keterangan

Independen

Lag_Nilai Tukar $\quad 0,508$

Lag_SBI $\quad 0,732$

Lag_Inflasi $\quad 0,768$

Tidak Terjadi Heterokedastisitas
Tidak Terjadi Heterokedastisitas
Tidak Terjadi Heterokedastisitas

Tidak Terjadi Heterokedastisitas

Tidak Terjadi Heterokedastisitas
Macroeconomic factors in

Composite Stock

Proce Index

\section{Sumber: Data diolah 2021}

Berdasarkan tabel 5 di atas terlihat bahwa Sig $>0,05$. Nilai signifikansi dari variabel Nilai Tukar sebesar 0,508, nilai dari Suku Bunga SBI sebesar 0,738, dan nilai dar Inflasi sebesar 0,768, sehingga dapat disimpulkan bahwa bahwa ke empat variabel tersebut tidak terjadi heterokesdastisitas.

\section{Tabel 6 Analisis Regresi Berganda}

Analisis regresi linear berganda digunakan untuk mengetahui pengaruh dua atau lebih variabel independent $(\mathrm{X})$ terhadap variabel dependent $(\mathrm{Y})$. Dalam penelitian ini, analisis regresi digunkan untuk menguji pengaruh Nilai Tukar, Suku Bunga SBI, dan Inflasi terhadap Indeks Harga Saham Gabungan.

Hasil Uji Analisis Regresi Berganda

\begin{tabular}{llll}
\hline Model & $\mathrm{B}$ & $\mathrm{t}$ & Sig. \\
\hline (Constant) & 1188,678 & 11,461 & 0,000 \\
Lag_NilaiTukar & $-0,361$ & $-6,341$ & 0,000 \\
Lag_SBI & $-11,295$ & $-0,111$ & 0,912 \\
Lag_Inflasi & $-73,692$ & $-0,901$ & 0,372 \\
\hline
\end{tabular}

a. Dependent Variable: Lag_IHSG

Sumber: Data diolah 2021

Dari hasil uji regresi linear berganda pada tabel 6, diketahui pengaruh variabel (Nilai Tukar, Suku Bunga SBI, Inflasi) terhadap variabel dependent (Indeks Harga Saham Gabungan), maka dapat disusun persamaan regresi linear berganda sebagai berikut:

$\hat{\mathbf{Y}}=1188,678-0,361$ NilaiTukar - 11,295SBI - 73,692Inflasi $+e$

\section{Uji Hipotesis}

\section{Tabel 7 Uji Simultan (Uji F)}

Hasil Uji Simultan (Uji F)

\begin{tabular}{lll}
\hline Model & F & Sig \\
\hline $1 \quad$ Regression & 14,002 & $0,000^{\mathrm{a}}$ \\
Residual & & \\
Total & & \\
Sumber: Data diolah 2021 & &
\end{tabular}

Berdasarkan Tabel 7 dapat diketahui nilai F-hitung 14,002 dan tingkat signifikansi dari nilai $\mathrm{F}$ adalah sebesar 0,000, karena tingkat signifikansi lebih kecil dari 0,05\%. Maka dapat disimpulkan bahwa $\mathrm{H}_{0}$ ditolak dan $\mathrm{H}_{a}$ diterima, yang artinya bahwa variabel Nilai Tukar, Suku Bunga SBI dan Inflasi berpengaruh positif dan signifikan secara simultan terhadap Indeks Harga Saham Gabungan. 
Macroeconomic

factors in

Composite Stock

Proce Index

216
Tabel 8 Uji Koefisien Determinasi $\left(\mathbf{R}^{2}\right)$

Uji Koefisien Determinasi $\left(\mathrm{R}^{2}\right)$

\begin{tabular}{ll}
\hline Adjusted R Square & Std. Error of thr Estimate \\
\hline 0,402 & 174,14646 \\
\hline
\end{tabular}

Sumber: Data diolah 2021

Berdasarkan tabel diatas maka diperoleh nilai $\mathrm{R}$ Square $\left(\mathrm{R}^{2}\right)$ sebesar 0,402 atau 40,2\% menunjukkan kontribusi dari variabel bebas Nilai Tukar, Suku Bunga SBI, dan Inflasi terhadap variabel terikat yaitu Indeks Harga Saham Gabungan sedangkan sisanya sebesar $59,8 \%$ dipengaruhi oleh faktor lain yang tidak masuk dalam model penelitian yang pengaruhnya cukup besar.

Tabel 9 Hasil Uji t

Hasil Uji t

\begin{tabular}{llll}
\hline Model & $\begin{array}{l}\text { Unstandardized } \\
\text { Coefficients }\end{array}$ & $\mathrm{t}$ & Sig \\
& $\mathrm{B}$ & & \\
\hline (Constan) & 1188,678 & 11,461 & 0,000 \\
Lag_NilaiTukar & $-0,361$ & $-6,341$ & 0,000 \\
Lag_SBI & $-11,295$ & $-0,111$ & 0,912 \\
Lag_Inflasi & $-73,692$ & $-0,901$ & 0,372 \\
\hline
\end{tabular}

a. Dependent Variable: Lag_IHSG

Sumber: Data diolah 2021

Pengaruh Nilai Tukar terhadap Indeks Harga Saham Gabungan

Pengujian pengaruh Nilai Tukar terhadap Indeks Harga Saham Gabungan diperoleh thitung sebesar -6,341 yang bertanda negatif dengan nilai signifikansi 0,000 yang berarti lebih kecil dari taraf signifikansi yaitu $0,05(0,000<0,05)$ hal ini menunjukan bahwa $\mathrm{H}_{0}$ ditolak $\mathrm{H}_{\mathrm{a}}$ diterima, sehingga dapat disimpulkan bahwa Nilai Tukar berpengaruh negatif dan signifikan terhadap Indeks Harga Saham Gabungan periode 2016-2020.

Pengaruh Suku Bunga terhadap Indeks Harga Saham Gabungan

Pengujian pengaruh Suku Bunga SBI terhadap Indeks Harga Saham Gabungan diperoleh t hitung sebesar $-0,111$ yang bertanda negatif dengan nilai signifikansi 0,912 yang berarti lebih besar dari taraf signifikansi yaitu $0,05(0,912>0,05)$ hal ini menunjukan bahwa $\mathrm{H}_{0}$ diterima $\mathrm{H}_{\mathrm{a}}$ ditolak, sehingga dapat disimpulkan bahwa Suku Bunga SBI berpengaruh negatif dan tidak signifikan terhadap Indeks Harga Saham Gabungan periode 2016-2020.

Pengaruh Inflasi terhadap Indeks Harga Saham Gabungan

Pengujian pengaruh Inflasi terhadap Indeks Harga Saham Gabungan diperoleh t hitung sebesar -0,901 yang bertanda negatif dengan nilai signifikansi 0,372 yang berarti lebih besar dari taraf signifikansi yaitu $0,05(0,372>0,05)$ hal ini menunjukan bahwa $\mathrm{H}_{0}$ diterima $\mathrm{H}_{\mathrm{a}}$ ditolak, sehingga dapat disimpulkan bahwa Inflasi berpengaruh negatif dan tidak signifikan terhadap Indeks Harga Saham Gabungan periode 2016-2020.

\section{Pembahasan}

\section{Pengaruh Nilai Tukar terhadap Indeks Harga Saham Gabungan}

Berdasarkan hasil pengujian hipotesis dapat diketahui bahwa nilai tukar (kurs) secara parsial berpengaruh signifikan terhadap pergerakan indeks harga saham gabungan (IHSG). Hal ini ditunjukkan oleh nilai sig. t lebih kecil dari taraf signifikan yang disyaratkan yaitu $0,000<0,05$ yang artinya $\mathrm{H}_{0}$ ditolak dan $\mathrm{H}_{\mathrm{a}}$ diterima. Variabel nilai tukar menunjukkan pengaruh yang negatif terhadap IHSG. Semakin rendah nilai tukar maka harga saham akan menurun atau sebaliknya. Hal ini ditunjukkan oleh nilai koefisien $-6,341$ dan bertanda negatif, artinya setiap penurunan nilai tukar sebesar 1 nilai mata uang maka IHSG akan menurun sebesar 6,341 satuan poin IHSG, dengan asumsi cateris paribus. Nilai tukar rupiah 
berpengaruh secara parsial terhadap IHSG, hal ini berarti bahwa investor saham mencermati pergerakan tingkat nilai tukar rupiah untuk membuat keputusan investasi. Hasil penelitian ini bertentangan dengan penelitian yang dilakukan oleh Sudarsana \& Candraningrat (2014) dan Ardelia \& Saparila (2018) dimana Nilai Tukar rupiah memiliki pengaruh negatif dan signifikan terhadap Indeks Harga Saham Gabungan.

\section{Pengaruh Suku Bunga terhadap Indeks Harga Saham Gabungan}

Berdasarkan hasil pengujian hipotesis, diketahui bahwa suku bunga secara parsial berpengaruh tidak signifikan terhadap pergerakan indeks harga saham gabungan (IHSG). $\mathrm{Hal}$ ini ditunjukkan oleh nilai sig. t lebih besar dari taraf signifikan yang disyaratkan yaitu 0,912>0,05 yang artinya $\mathrm{H}_{0}$ diterima dan $\mathrm{H}_{\mathrm{a}}$ ditolak. Hubungan tidak signifikan ini dikarenakan tipe investor yang senang melakukan transaksi saham dalam jangka pendek (trader/spekulan), sehingga investor cenderung melakukan aksi profit taking dengan harapan memperoleh capital gain yang cukup tinggi di pasar modal (Kewal, 2012). Selain itu periode yang digunakan terlalu singkat yaitu lima tahun, jadi hasil yang diperoleh kurang jelas. Variabel suku bunga menunjukkan hubungan yang negatif terhadap IHSG, yang berarti setiap fluktuasi suku bunga berbanding terbalik dengan IHSG. Semakin rendah suku bunga maka harga saham akan meningkat atau sebaliknya. Hal ini ditunjukkan oleh nilai koefisien $-0,111$ dan bertanda negatif, artinya setiap penurunan suku bunga sebesar $1 \%$ akan berpengaruh terhadap kenaikan IHSG sebesar 0,111 satuan poin IHSG, dan sebaliknya setiap kenaikan suku bunga sebesar 1\% akan berpengaruh terhadap penurunan IHSG sebesar $-0,111$ satuan poin IHSG dengan asumsi cateris paribus. Hubungan negatif antara suku bunga dengan IHSG ini sesuai dengan teori Eduardus bahwa perubahan suku bunga akan memengaruhi harga saham secara terbalik, cateris paribus, yaitu jika suku bunga meningkat, maka harga saham akan turun karena masyarakat akan mengalihkan investasinya dari pasar modal (saham) ke sektor lain seperti pada perbankan (deposito maupun tabungan). Hasil penelitian ini sama dengan hasil penelitian yang dilakukan oleh Krisna \& Wirawati (2013) dan Kumalasari (2016) dimana Suku Bunga SBI memiliki pengaruh negatif dan tidak signifikan terhadap Indeks Harga Saham Gabungan.

\section{Pengaruh Inflasi terhadap Indeks Harga Saham Gabungan}

Berdasarkan hasil pengujian hipotesis, diketahui bahwa inflasi secara parsial tidak signifikan memengaruhi pergerakan indeks harga saham gabungan (IHSG). Hal ini ditunjukkan oleh nilai sig. t lebih besar dari taraf signifikan yang disyaratkan yaitu 0,372 > 0,05 yang artinya $\mathrm{H}_{0}$ diterima dan $\mathrm{H}_{\mathrm{a}}$ ditolak. Pengaruh yang tidak signifikan ini karena selama periode pengamatan tingkat inflasi berada dalam kategori inflasi ringan yaitu di bawah $10 \%$ dan periode yang digunakan juga terlalu singkat yaitu lima tahun, jadi hasil yang diperoleh kurang jelas. Selain itu naik turunnya inflasi kurang diperhatikan oleh para investor. Investor sepertinya lebih cenderung menunggu dalam mengambil keputusan investasi sampai keadaan perekonomian kondusif dan melihat kebijakan yang di ambil oleh pemerintah dalam mengatasi masalah inflasi. Di sisi lain masih banyak faktor lain yang memengaruhi harga saham seperti keadaan politik, keamanan dan isu-isu yang bisa memengaruhi para investor dalam memperjualbelikan saham. Hasil penelitian ini membuktikan bahwa tingkat inflasi bukan merupakan faktor penentu dalam menjelaskan perubahan IHSG. Sehingga walaupun terjadi peningkatan pada inflasi, investor tetap dapat mempertahankan sahamnya karena tidak ada pengaruh yang signifikan dari tingkat inflasi terhadap IHSG (Maurina \& Sulasmiyati, 2015). Variabel inflasi menunjukkan hubungan yang negatif terhadap IHSG, yang berarti setiap fluktuasi inflasi berbanding terbalik dengan IHSG. Semakin tinggi inflasi maka harga saham akan menurun atau sebaliknya. Hal ini ditunjukkan oleh nilai koefisien $-0,901$ dan bertanda negatif, artinya setiap penurunan inflasi sebesar 1\% akan berpengaruh terhadap kenaikan IHSG sebesar 0,901 satuan poin IHSG, sebaliknya setiap kenaikan inflasi sebesar $1 \%$ akan berpengaruh terhadap penurunan IHSG sebesar -0,901 satuan poin IHSG dengan asumsi cateris paribus. Sunariyah (2011) juga

\section{Macroeconomic \\ factors in \\ Composite Stock \\ Proce Index}


Macroeconomic

factors in

Composite Stock

Proce Index

218

menjelaskan bahwa inflasi yang tinggi menyebabkan turunnya kinerja keuangan suatu perusahaan, sehingga akan menurunkan pembagian dividen dan daya beli masyarakat juga menurun. Jika dividen yang merupakan salah satu aspek perhitungan dalam pembelian saham menurun, mencerminkan profitabilitas perusahaan juga menurun. Profitabilitas sebuah perusahaan yang menurun membuat investor akan melepas saham yang dimilikinya. Minat investor juga akan menurun untuk membeli saham jika profitabilitas sebuah perusahaan menurun yang disebabkan oleh inflasi. Hal tersebut juga akan membuat indeks harga saham cenderung akan menurun karena dampak dari inflasi yang membuat profitabilitas perusahaan menurun sehingga inflasi merupakan sebuah informasi yang negatif bagi para investor di pasar modal. Hasil penelitian ini sama dengan hasil penelitian yang dilakukan oleh Ardelia \& Saparila (2018), Krisna \& Wirawati (2013) dan Kumalasari (2016) dimana Inflasi memiliki pengaruh negatif dan tidak signifikan terhadap Indeks Harga Saham Gabungan.

Pengaruh Nilai Tukar, Suku Bunga dan Inflasi terhadap Indeks Harga Saham Gabungan Berdasarkan hasil pengujian hipotesis, diketahui bahwa nilai tukar, suku bunga dan inflasi secara simultan berpengaruh signifikan terhadap Indeks Harga Saham Gabungan (IHSG) pada periode tahun 2016-2020. Hasil analisis secara simultan menunjukkan bahwa nilai signifikansi sebesar 0,000 $<0,05$ sehingga hipotesis keempat diterima. Nilai koefisien determinasi (Adjusted R Square) yang diperoleh dari tabel 4.8 sebesar 0,402 atau 40,2\%. Nilai tersebut menunjukkan bahwa pergerakan Indeks Harga Saham Gabungan (IHSG) pada periode 2016-2020 dipengaruhi oleh variabel nilai tukar rupiah, suku bunga dan inflasi sebesar 40,2\%, sedangkan sisanya sebesar 59,8\% dipengaruhi oleh faktor lain yang tidak masuk dalam model penelitian yang pengaruhnya cukup besar. Hasil penelitian ini mendukung penelitian Kewal (2012) yang mengungkapkan bahwa inflasi, suku bunga, kurs, dan pertumbuhan PDB berpengaruh secara simultan terhadap Indeks Harga Saham Gabungan. Hasil penelitian ini juga mendukung penelitian Jayanti (2014) bahwa Tingkat Inflasi, Tingkat Suku Bunga SBI, Nilai Tukar Rupiah, Indeks Dow Jones, dan Indeks KLSE berpengaruh secara simultan terhadap Indeks Harga Saham Gabungan.

\section{PENUTUP}

Berdasarkan hasil penelitian dan pembahasan penelitian diatas dapat disimpulkan sebagai berikut:

1. Terdapat pengaruh negatif dan signifikan Nilai Tukar terhadap Indeks Harga Saham Gabungan di Bursa Efek Indonesia

2. Terdapat pengaruh negatif dan tidak signifikan Suku Bunga terhadap Indeks Harga Saham Gabungan di Bursa Efek Indonesia.

3. Terdapat pengaruh negatif dan tidak signifikan Inflasi terhadap Indeks Harga Saham Gabungan di Bursa Efek Indonesia.

4. Terdapat pengaruh positif dan signifikan Nilai Tukar, Suku Bunga dan Inflasi terhadap Indeks Harga Saham Gabungan di Bursa Efek Indonesia.

\section{DAFTAR PUSTAKA}

[1]. Adelin, D. (2019). Determinants Changes Composite Stock Price Index ( Jci ) in Indonesia Stock Exchange ( Bei ). International Journal of Economics, Business and Management Research, 3(05), 127-139.

[2]. Akua Miyanti, G. A. D., \& Wiagustini, L. P. (2018). Pengaruh Suku Bunga the Fed, Harga Minyak Dan Inflasi Terhadap Indeks Harga Saham Gabungan (Ihsg) Di Bursa Efek Indonesia. E-Jurnal Ekonomi Dan Bisnis Universitas Udayana, 5, 1261. https://doi.org/10.24843/eeb.2018.v07.i05.p02

[3]. Amin, M. Z. (2012). PENGARUH TINGKAT INFLASI, SUKU BUNGA SBI, NILAI 
KURS DOLLAR (USD/IDR), DAN INDEKS DOW JONES (DJIA) TERHADAP PERGERAKAN INDEKS HARGA SAHAM GABUNGAN DI BURSA EFEK INDONESIA (BEI) (PERIODE 2008-2011). 1-17.

[4]. Ardelia, \& Saparila. (2018). PENGARUH INFLASI, SUKU BUNGA, DAN NILAI TUKAR RUPIAH TERHADAP INDEKS HARGA SAHAM GABUNGAN (Studi pada Bursa Efek Indonesia Periode 2013-2017). 60(2).

[5]. Astuti, R., Susanta, H., \& Apriatni. (2013). Analisis Pengaruh Tingkat Suku Bunga ( SBI ), Nilai Tukar ( Kurs ) Rupiah, Inflasi , Dan Indeks Bursa Internasional Terhadap Ihsg. Diponegoro Journal of Social and Politic of Science, 1-10.

[6]. Bodie. (2015). Essential of Investments. McGraw-Hill Higher Education.

[7]. Devi Dwi Wulandari, Novi Puspitasari, \& Ana Mufida. (2020). Pengaruh Inflasi, Nilai Tukar, Dan Suku Bunga Terhadap Indeks Harga Saham Gabungan Di Bursa Efek Negara-Negara ASEAN. Relasi: Jurnal Ekonomi, 16(1), 164-178. https://doi.org/10.31967/relasi.v16i1.346

[8]. Dewi Martha Sofia \& Lena Farida. (2017). Pengaruh Kebijakan Dividen, Kebijakan Hutang, Dan Keputusan Investasi Terhadap Nilai Perusahaan Pada Sub Sektor Perdagangan Besar Yang Terdaftar Di Bursa Efek Indonesia Periode 2010-2014. Jom Fisip, 4(4), 1-15.

[9]. Gendro Wiyono. (2011). Merancang Penelitian Bisnis Dengan Alat Analisis SPSS 17.0 \& SmartPLS 2.0. UPP STIM YKPN.

[10]. Ghozali. (2011). Aplikasi Analisis Multivariate dengan Program IBM SPSS. Badan Penerbit Universitas Diponegoro.

[11]. Husnul, H. M., Hidayat, R. R., \& Sulasmiyati, S. (2017). Analisis pengaruh inflasi, kurs (IDR/USD), Produk Domestik Bruto dan harga emas dunia terhadap Indeks Harga Saham Gabungan (Studi Pada Indonesia Periode 2008 - 2016). Jurnal Administrasi Bisnis, 53(1), 66-74. http://administrasibisnis.studentjournal.ub.ac.id/index.php/jab/article/view/2183

[12]. Jayanti, Y. (2014). PENGARUH TINGKAT INFLASI, TINGKAT SUKU BUNGA SBI, NILAI TUKAR RUPIAH, INDEKS DOW JONES, DAN INDEKS KLSE TERHADAP INDEKS HARGA SAHAM GABUNGAN (IHSG) Studi Pada Bursa Efek Indonesia Periode Januari 2010 â Desember 2013. Jurnal Administrasi Bisnis S1 Universitas Brawijaya, 11(1), 82780.

[13]. Kewal, S. S. (2012). Pengaruh Inflasi, Suku Bunga, Kurs, Dan Pertumbuhan Pdb Terhadap Indeks Harga Saham Gabungan. Jurnal Economia, 8(1), 53-64. https://doi.org/10.21831/economia.v8i1.801

[14]. Krisna, \& Wirawati. (2013). PENGARUH INFLASI, NILAI TUKAR RUPIAH, SUKU BUNGA SBI PADA INDEKS HARGA SAHAM GABUNGAN DI BEI. EJurnal Akuntansi, 3.

[15]. Kumalasari. (2016). PENGARUH NILAI TUKAR, BI RATE, TINGKAT INFLASI, DAN PERTUMBUHAN EKONOMI TERHADAP INDEKS HARGA SAHAM GABUNGAN (Studi Pada Indeks Harga Saham Gabungan Di BEI Periode Juli 2005Juni 2015). Jurnal Administrasi Bisnis S1 Universitas Brawijaya, 34(1), 130-137.

[16]. Kusuma, I., \& Badjra, I. (2016). Pengaruh Inflasi, Jub, Nilai Kurs Dollar Dan Pertumbuhan Gdp Terhadap Ihsg Di Bursa Efek Indonesia. E-Jurnal Manajemen Universitas Udayana, 5(3), 255199.

[17]. Maurina, Y., \& Sulasmiyati, R. R. H. S. (2015). PENGARUH TINGKAT INFLASI, KURS RUPIAH DAN TINGKAT SUKU BUNGA BI RATE TERHADAP IHSG (Studi Pada Bursa Efek Indonesia Periode 2010-2014). Jurnal Administrasi Bisnis S1 Universitas Brawijaya, 27(2), 86383.

[18]. Mohamad Ridwan. (2013). ANALISIS MAKRO EKONOMI TERHADAP RETURN LQ
Macroeconomic factors in Composite Stock Proce Index

219 
Macroeconomic

factors in

Composite Stock

Proce Index

220

45 DAN DAMPAKNYA TERHADAP IHSG. 84, 487-492. http://ir.obihiro.ac.jp/dspace/handle/10322/3933

[19]. Nugroho, P. W. (2012). ANALISIS FAKTOR-FAKTOR YANG MEMPENGARUHI INFLASI DI INDONESIA PERIODE 2000 - 2011. Skripsi, 83.

[20]. Sudarsana, N. M. A. D., \& Candraningrat, I. R. (2014). PENGARUH SUKU BUNGA SBI, NILAI TUKAR, INFLASI DAN INDEKS DOW JONES TERHADAP INDEKS HARGA SAHAM GABUNGAN DI BEI. 3291-3308.

[21]. Wijaya, T. S. J., \& Agustin, S. (2015). Faktor-Faktor yang Mempengaruhi Nilai IHSG yang Terdaftar di Bursa Efek Indonesia. Jurnal Ilmu Dan Riset Manajemen, 4(6), 1-16. 